\title{
Is a Physician Armed with Soft Skills More Successful?
}

\author{
Gurmeet Singh Sarla* \\ Department of General Surgery, Military Hospital Devlali, India
}

Submission: June 03, 2019; Published: July 01, 2019

*Corresponding author: Gurmeet Singh Sarla, Senior Advisor Surgery Military Hospital Devlali, Devlali, Nasik Maharashtra, India

\begin{abstract}
Soft skills are also known as people's skill or non-technical skills. They are a cluster of productive personality traits that characterize one's relationships in a milieu. They define your relationship with others or how you approach life and work. The communication skills of physician impacts patients' satisfaction and is an effective step of making effective relationship between doctor and patient. A Physician who does not have the soft skills of emotional intelligence, trustworthiness and approachability is not very highly regarded by their patients. In the corporate world, most organisations including large corporate hospitals have started investing a great deal of time and effort in elaborating training programmes designed to improve soft skills. Soft skills are the difference between adequate candidates and ideal candidates. A leader has a combination of hard and soft skills in right proportions. The communication skills of physicians play a major role in clientele satisfaction and trustfulness of patients on their doctors. Making the patient participate in planning the plan of action or the treatment plan by explanation of diagnosis and treatment process plays an important role in driving the satisfaction of patients. Courteous, approachable, smiling, soft spoken, empathetic Physicians with friendly behaviour have shown to have better doctor patient relationship and better patient satisfaction levels.
\end{abstract}

Keywords: Biostatistics; Researchers; Statistics; Interpret; Collaboration; Clinician; Progression; Medicine; Limitations; Interpretation; Translation

\section{Introduction}

Soft skills are desirable qualities that do not depend upon acquired knowledge: they include common sense, ability to deal with people and a positive flexible attitude. They are also known as transferrable skills, people's skills or social skills. They define your relationship with others or how you approach life and work. Ironically soft skills are hardest skills to develop, however they can also be taught and learnt. They are your ability to recognise and manage your own and others' emotions. Unlike hard skills there is no exam which proves that you have them, however they can be roughly estimated by how well you manage relationships with your family, friends and co-workers.

\section{Hard Skills}

Hard skills are job specific skills and are specific, teachable abilities that can be defined and measured, such as bricklaying accountancy, typing, writing, math, reading, diagnosing a particular disease and the ability to use software programs.

\section{What are Soft Skills?}

Soft skills are also known as people's skill or non-technical skills. They are less tangible and harder to quantify, such as etiquette, getting along with others, listening and engaging in small talk. They are a cluster of productive personality traits that char acterize one's relationships in a milieu. These skills can include social graces, communication abilities, language skills, personal habits, cognitive or emotional empathy, time management, teamwork and leadership traits. Soft skills have more to do with who people are, rather than what they know. The term soft skill describes a person's Emotional Intelligence Quotient (EQ) rather than his Intelligence Quotient (IQ). Soft skills predict success in life, and programs that enhance soft skills have an important place in an effective portfolio of public policies [1].

IQ tests, standardized achievement tests, and grades are often interchangeably used to measure "cognitive ability" [2]. Success in life depends on personality traits like conscientiousness, perseverance, sociability, and curiosity that are not well captured by measures of cognition. A substantial body of evidence shows that stable traits exist. People tend to behave in the same fashion across a wide range of situations [3]. Evidence from genetics and neuroscience provides a biological basis for the existence of such traits, suggesting that something tied to the person, not the just the situation, affects behaviour [4].

Fluid intelligence is the rate at which people learn and crystalized intelligence is acquired knowledge [5]. Achievement tests are heavily weighted towards crystallized intelligence [6]. 
IQ tests are heavily weighted toward fluid intelligence [7]. Personality traits are manifested through thoughts, feelings, and behaviours. Personality traits are the "Big Five," which includes Openness to Experience, Conscientiousness, Extraversion, Agreeableness, and Neuroticism [8].

People who score low on openness are closed to experience. They tend to be conventional and traditional in their outlook and behaviour. They prefer familiar routines to new experiences, and generally have a narrower range of interests. Conscientiousness is the personality trait of being careful, or diligent. It implies a desire to do a task well, and to take obligations to others seriously. Conscientious people tend to be efficient and organized as opposed to easy-going and disorderly. Extraversion indicates how outgoing and social a person is. People who score high in extraversion enjoy being with people, participating in social gatherings, and are full of energy. Agreeableness is a personality trait manifesting itself in individual behavioural characteristics that are perceived as kind, sympathetic, cooperative, warm, and considerate. Individuals who score high on neuroticism are more likely to be moody and to experience such feelings as anxiety, worry, fear, anger, frustration, envy, jealousy, guilt, depressed mood, and loneliness.

A large body of evidence shows that stable personality traits exist and are predictive of many behaviours [9]. There is compelling evidence that, averaging over tasks and situations at a point in time, people act in a predictable fashion with a high level of reliability of average behaviour across situations. Conscientiousness predicts educational attainment more than either of the facets of intelligence [10].

\section{Why are soft skills important for physicians?}

The communication skills of Physician impacts patients' satisfaction and is an effective step of making effective relationship between doctor and patient. The Physician's ability to communicate well with his patient is the most important part of medical art is called the heart and art of medication [11]. A Physician who does not have the soft skills of emotional intelligence, trustworthiness and approachability is not very highly regarded by their patients. Physicians who don't communicate with their patients efficiently may fall in a wrong cycle such as patients' dissatisfaction, increased mistakes, misdiagnosing, increased costs of health care services, prescribing unnecessary drugs, wasting the time and money of patients, which may lead to the wrong treatment process causing decreasing quality of health services [12]. When patients are dissatisfied, their real message is that their emotional needs are not being met [13]. They may feel disrespected, confined, vulnerable, fearful and lonely and they expect the healthcare provider to treat these emotional needs too [13]. According to the statements of patients, the friendly communication of doctors are the most important sources of their mental and spiritual support [14].

The skill of tolerantly listening to the patients extremely helps for creating a trustworthy relationship between Physician and patient which is an essential step for therapeutic success [15]. Gross et al. [16] found that there was a direct relationship between devoting enough time for visiting the patient and the satisfaction level of patients [16]. Rezaei et al. [17] showed that there is a meaningful correlation between showing the interest by physician for listening to their patients and the satisfaction of patients [17]. A study by Suh revealed that explanation of diagnosis and treatment process plays an important role in driving the satisfaction of patients [18]. Korsch et al. [19] showed that there is a significant relationship between patients' satisfaction and respectful behaviour of physicians [19]. It was further shown that lack of warmth and friendly communication of Physicians, failure in taking into consideration the patient's concerns and their expectations from medical visits, the lack of clear diagnosis explanation and causation of disease and use of medical jargon lead significantly to the patient dissatisfaction [19]. Soft skills increase confidence, professionalism, coordination, friendliness and optimism in an individual [20]. At certain times, Physicians are perceived by the patients to apparently ignore and not to care about them. This is because they are ill-equipped emotionally by way of their training [21].

\section{Recruiters World Over Are Looking for Soft Skills}

In the corporate world, most organisations including large corporate hospitals have started investing a great deal of time and effort in elaborating training programmes designed to improve soft skills. Human resource managers and top recruiters who come for campus selections to IITs and IIMs hire young people who have soft skills in addition to their professional competence. This demonstrates that companies understand the value of soft skills and their impact on their organisations. Business executives consider soft skills a very important attribute in job applicants [22]. Soft skills are the difference between adequate candidates and ideal candidates. In most competitive job markets, recruitment criteria do not stop at technical ability and specialist knowledge, but recruiters look for a balance of hard skills and soft skills when making hiring decisions. A study reveals that hard skills contribute to only $15 \%$ of one's success while the remaining $85 \%$ is made by soft skills [23].

\section{Does a leader have soft skills?}

Leadership is not soft, it is hard. The general perception of a popular leader is of an authoritarian who speaks well, is meticulous in his job and has many followers. A leader has a combination of hard and soft skills in right proportions. Leaders are expected to have good oratory skills, but good leaders also are patient listeners. Negotiation and motivation are a big part of the job for leaders. When negotiating with employees, clients, or associates, leaders need to be skilled in staying considerate of what others want while remaining focused on pushing for what they want. Good leaders also need to know how to make their own work most efficient by strategically delegating tasks to workers. 


\section{Conclusion}

Success in life depends on personality traits in addition to those measured by IQ, grades, and standardized achievements tests. The communication skills of Physicians play a major role in clientele satisfaction and trustfulness of patients on their doctors. Communication skills of Physicians are considered as core skills required to be a successful healer.

There is a significant relationship between length of time devoted for visiting the patient and the satisfaction level of patients. Letting the patient speak and giving a patient hearing improves patient satisfaction levels. Making the patient participate in planning the plan of action or the treatment plan by explanation of diagnosis and treatment process plays important role in driving the satisfaction of patients. Courteous, approachable, smiling, soft spoken, empathetic Physicians with friendly behaviour have shown to have better doctor patient relationship and better patient satisfaction levels.

\section{References}

1. (2007) The ACT Technical Manual. Iowa City, IA: ACT.

2. Ayllon T, Kelly K (1972) Effects of reinforcement on standardized test performance. Journal of Applied Behaviour Analysis 5(4): 477-484.

3. Barrick MR, Mount MK (1991) The Big Five personality dimensions and job performance: A meta-analysis. Personnel Psychology 44(1): 1-26.

4. Baumeister RF, Tierney JJM (2011) Willpower: Rediscovering the Greatest Human Strength. New York: Penguin Press.

5. Bouchard TJ, Loehlin JC (2001) Genes, evolution and personality. Behaviour Genetics 31(3): 243-273.

6. Bound J, Brown C, Mathiowetz N (2001) Measurement error in survey data. In: Heckman JJ, Leamer E, (Eds.), Handbook of Econometrics. Volume 5 of Handbooks in Economics Amsterdam: Elsevier Science pp. 3705-3843.

7. Bowen WG, Chingos MM, Mc Pherson MS (2009) Crossing the Finish Line: Completing College at America's Public Universities. Princeton, NJ: Princeton University Press, Test scores and high school grades as predictors, pp. 416.

8. Cattan S (2012) Heterogeneity and selection in the labor market.
9. Devlin B, Daniels M, Roeder K (1997) The heritability of IQ. Nature 388(6641): 468-471.

10. Durlak JA, Weissberg RP, Dymnicki AB, Taylor RD, Schellinger KB (2011) The impact of enhancing students' social and emotional learning: A meta-analysis of school-based universal interventions. Child Development 82(1): 405-432.

11. Ha J, Longnecker N (2010) Doctor-patient communication: a review. The Ochsner Journal 10(1): 38-43.

12.Zamani A, Shams B, Farajzadegan Z, Tabaian M (2003) The Viewpoints of Clinical Faculty Members about Teaching Communication Skills to Medical Students. Iranian Journal of Medical Education 3(1): 45-55.

13. Gurmeet Singh Sarla (2019) Physicians Versus Administrators: A Perspective. J Complement Med Alt Healthcare 9(3): 1-3.

14. Baile WF, Buckman R, Lenzi R, Glober G, Beale EA, et al. (2000) SPIKES - a six-step protocol for delivering bad news: application to the patient with cancer. Oncologist 5(4): 302-311.

15. Kelly L (1998) Listening to patients: a lifetime perspective from Ian McWhinney. CJRM 3(3): 168-169.

16. Gross DA, Zyzanski SJ, Borawski EA, Cebul RD, Stange KC (1998) Patient satisfaction with time spent with their physician. J Fam Pract 47(2): 133-137.

17. Rezaei F, Askari HA (2014) Checking the relationship between physicians' communication skills and outpatients' satisfaction in the clinics of Isfahan Al-Zahra (S) Hospital in 2011. J Educ Health Promot 28(3): 105.

18. Suh WS, Lee CK (2010) Impact of Shared-Decision Making on Patient Satisfaction. J Prev Med Public Health 43(1): 26-34.

19. Korsch BM, Gozzi EK, Francis V (1968) Gaps in doctor-patient communication-I: Doctor-patient interaction and patient satisfaction. Paediatrics 42(5): 855-871.

20. Dalaya M, Ishaquddin S, Ghadage M, Hatte G (2015) An interesting review on soft skills and dental practice. J Clin Diagn Res 9(3): 19-21.

21. Deepa S, Seth M (2013) Do soft skills matter? - Implications for educators based on recruiter' perspective. The IUP Journal of Soft Skills 7(1): 7-20.

22. Jain S, Anjuman ASS (2013) Facilitating the acquisition of soft skills through training. The IUP Journal of Soft Skills 7(2): 32-39.

23. Wats M, Wats RK (2009) Developing soft skills in students. International Journal of Learning 15(12): 1-10.

\section{Your next submission with Juniper Publishers} will reach you the below assets

- Quality Editorial service

- Swift Peer Review

- Reprints availability

- E-prints Service

- Manuscript Podcast for convenient understanding

- Global attainment for your research

- Manuscript accessibility in different formats

( Pdf, E-pub, Full Text, Audio)

- Unceasing customer service

Track the below URL for one-step submission https://juniperpublishers.com/online-submission.php 